\title{
Publisher Correction to: The KOF Globalisation Index - revisited
}

\section{Savina Gygli ${ }^{1}$ • Florian Haelg ${ }^{2}$ - Niklas Potrafke ${ }^{3,4} \cdot$ Jan-Egbert Sturm ${ }^{2,5}$}

Published online: 1 May 2019

(C) Springer Science+Business Media, LLC, part of Springer Nature 2019

\section{Publisher Correction to: The Review of International Organizations https://doi.org/10.1007/s11558-019-09344-2}

The article listed above was initially published with incorrect copyright information due to a technical error on the publisher side.

Upon publication of this Correction, the copyright of this article changed to "The Author(s)".

The original article has been corrected.

Publisher's note Springer Nature remains neutral with regard to jurisdictional claims in published maps and institutional affiliations.

The online version of the original article can be found at https://doi.org/10.1007/s11558-019-09344-2

Florian Haelg

haelg@kof.ethz.ch

1 SNB, Zurich, Switzerland

2 KOF Swiss Economic Institute, ETH Zurich, Leonhardstrasse 21, 8092 Zurich, Switzerland

3 Ifo Institute, Munich, Germany

4 University of Munich, Munich, Germany

5 CESifo Munich, Munich, Germany 